\title{
Factors associated with low serum retinol levels in children aged 6-24 months in a rural South African community
}

\author{
Mieke Faber* and AJ Spinnler Benadé \\ National Research Programme for Nutritional Intervention, Medical Research Council, PO Box 19070, \\ Tygerberg 7505, South Africa
}

Submitted 23 August 1999: Accepted 6 March 2000

\begin{abstract}
Objective: To identify risk factors for variation in serum retinol levels in children younger than 2 years of age in a rural South African community.

Design: Children $(n=97), 6-24$ months of age, were divided into two groups according to their serum retinol levels, using $20 \mu \mathrm{g} \mathrm{dl}^{-1}$ as the cut-off point. The chisquare test, Fischer exact two-tailed test and analysis of variance were used to identify related variables which were significantly different between the two groups. To evaluate simultaneously the association between several potential risk factors and low serum retinol levels, a multiple regression model for categorical data was developed which included potential risk factors that were statistically significant in the bivariate analysis as the independent variables, and either low or normal vitamin A status as the dependent variable.

Results: There was an association between serum retinol levels and: (i) the place of birth (hospital vs. home deliveries); (ii) the attitude of the care-giver towards family life; and (iii) the health status of the child. Although not included in the multiple variable model because of small numbers, all children who had a previous episode of measles, all underweight children, and all children of widowed care-givers were in the low serum retinol group.

Conclusions: The care-giver's attitude towards family life was positively associated with the child's vitamin A status, while home deliveries were associated with a low vitamin A status.
\end{abstract}

Keywords
Rural
Under 2s
Vitamin A
Risk factors
Vitamin A deficiency is a significant public health problem in many countries in the developing world and night blindness is possibly its earliest clinical manifestation. Although South Africa does not have a high prevalence of night blindness, subclinical vitamin A deficiency has been defined as a public health problem in preschool children, especially among children living in the rural areas ${ }^{1}$.

Vitamin A deficiency can be successfully addressed in the short term by periodic delivery of large doses of vitamin $\mathrm{A}^{2}$ and, in some situations, by food fortification ${ }^{3}$. In most developing countries, however, long-term prevention must rely on efforts to improve the quality of the local diet. For this, knowledge of dietary patterns is needed to target nutrition information to groups where needed. The relationship between food intake and malnutrition is, however, complex as indicated in UNICEF's conceptual model for child nutrition. In this model, the immediate causes of malnutrition (inadequate dietary intake and diseases) are influenced by three underlying factors, namely: (i) household food security; (ii) maternal and child care; and (iii) health services and environment ${ }^{4}$.

The objectives of intervention programmes should be to discourage behaviours that are associated with poor nutritional status, and to promote behaviours that are associated with good nutritional status. For the development of appropriate interventions to address vitamin A deficiency, identification of both positive and detrimental practices influencing the vitamin A status is needed. Positive and negative deviances are not necessarily mirror images of each other, and their determinants may be different.

In South Africa, as elsewhere, many children in poor households grow and develop normally, whereas others do not. These successful caring behaviour and support systems within the household and community may provide guidance in designing programmes in these communities.

Children presenting with clinical signs of vitamin A deficiency (e.g. night blindness) represent only a small proportion of children at risk for vitamin A-preventable morbidity and mortality, as many children present with subclinical vitamin A deficiency. Although epidemiological studies have shown associations between dietary practices, sociodemographic variables and occurrence of xerophthalmia ${ }^{5}$ and night blindness ${ }^{6}$, few studies ${ }^{7,8}$ have reported on the associations between blood vitamin $\mathrm{A}$ levels, dietary practices and sociodemographic variables. 
These factors usually vary according to local conditions, and can not be generalized.

The objective of this study was to identify demographic and socioeconomic risk factors and child care characteristics associated with variation in serum retinol levels in children aged 6-24 months in a rural South African community with a high prevalence of subclinical vitamin A deficiency ${ }^{9}$. This information could be used to identify groups at risk of vitamin A deficiency prior to the development of clinical signs, and to select the best means for combating this nutritional problem through policies and programmes designed to improve the nutritional status of children.

\section{Methods}

The study population resided in Ndunakazi, a mountainous rural area approximately $60 \mathrm{~km}$ from the coastal city of Durban in KwaZulu-Natal, South Africa. All children between 6 and 24 months of age who attended community-based growth-monitoring points (called Isizinda*) $)^{10}$ were recruited. (From data obtained from house-tohouse visits it is estimated that most children attend the Isizinda). The response rate was $79 \%$.

Venous blood $(5 \mathrm{ml})$ was obtained from 97 children by venepuncture by a paediatrician. Blood was processed and stored at $-80^{\circ} \mathrm{C}$ until assayed. Serum retinol levels were determined by reversed-phase high-performance liquid chromatography (HPLC), based on the method described by Catignani and Bieri ${ }^{11}$.

Anthropometric evaluation of the nutritional status of the children was assessed with regard to body weight and length as described by Jelliffe and Jelliffe ${ }^{12}$. Weight was measured to the nearest $0.05 \mathrm{~kg}$ on a load cell-operated digital scale (UC-300 Precision Health Scale). Recumbent body length was measured to the nearest $0.1 \mathrm{~cm}$ on a measuring board fitted with a measuring tape, a fixed headboard and a movable foot plate. The date of birth was obtained from the child's clinic card. The anthropometric data and age of the child were used to yield three measures of nutritional status: height-for-age, weight-forage and weight-for-height.

The mother $(n=71)$ or principal caretaker (a member of the household, usually the grandmother of the child; $n=26$ ), in whose care the child was during the day, was interviewed by a nutrition monitor (local people trained for the project) in her mother tongue (Zulu) using a structured questionnaire. The questionnaire was designed to collect information on socioeconomic conditions, demographic factors, household food security, health status and dietary and health care practices using the guidelines of Gross et al. ${ }^{13}$. Indicators of psychosocial care were the care-giver's knowledge of vitamin A, education,

*Community-based growth-monitoring points established in 1995 by the Medical Research Council, in close collaboration with the community. food beliefs, health status and social support received from family and the community. An unquantified food frequency questionnaire (previously tested and used in the same area) was used for qualitative assessment of the adequacy of food intake. Food items were listed, with space for the recording of additional food items consumed but not listed. To record the frequency of consumption of the food items listed, the participants had a choice of five options: (i) every day; (ii) most days (not every day, but at least 4 days per week); (iii) once a week (at least once a week, but less than 4 days per week); (iv) seldom (less than once per week); and (v) never.

Informed consent was obtained from the mother or principal caretaker (hereafter collectively referred to as care-givers) of the children.

\section{Statistical analysis}

Anthropometric data were analysed with Epi-Info 5 using the US National Center for Health Statistics (NCHS) growth reference data ${ }^{14}$, and expressed as Z-scores for each of the anthropometric indices of malnutrition. Children were defined as: (i) stunted or chronically undernourished if height-for-age Z-scores were below $-2 \mathrm{SD}$ of the median of the reference population; (ii) underweight if weightfor-age Z-scores were below $-2 \mathrm{SD}$ of the median of the reference population; (iii) wasted or acutely undernourished if weight-for-height Z-scores were below -2 SD of the median of the reference population; and (iv) overweight if weight-for-height Z-scores were above $2 \mathrm{SD}$ of the median of the reference population. The children were divided into two groups, namely low (serum retinol $<20 \mu \mathrm{g} \mathrm{dl}^{-1} ; n=38$ ) or normal (serum retinol $\geqslant 20 \mu \mathrm{g} \mathrm{dl}^{-1}$; $n=59)$.

In the bivariate analysis, variables that were statistically significant between the two groups were identified. Statistical comparisons of proportions were carried out using the chi-square test. For $2 \times 2$ tables in which one or more observed frequencies per cell were less than five, the Fischer exact two-tailed test was used. Analysis of variance was used to compare the means between the two groups.

To evaluate simultaneously the association between several potential risk factors and low serum retinol levels, a multiple variable regression model for categorical data was developed which included potential risk factors that were statistically significant in the bivariate analysis as the independent variables, and low or normal serum retinol levels as the dependent variable.

The SAS statistical programme (version 6.12) was used for statistical analysis. The 0.05 probability level was used to determine statistical significance.

\section{Results}

\section{Population characteristics}

The prevalence of low serum retinol levels $\left(<20 \mu \mathrm{g} \mathrm{dl}^{-1}\right)$ was $39.2 \%$, with a mean (SD) serum retinol level in the 
whole group of $22.1(6.5) \mu \mathrm{g} \mathrm{dl}{ }^{-1}$. Birth weights (obtained from the clinic cards) were available for 69 of the 75 children born in a hospital. The mean (SD) birth weight was 3163 (355) g and the prevalence of low birth weight $(<2500 \mathrm{~g})$ was $2.9 \%$. Characteristics of the two groups (low and normal serum retinol levels) are listed in Table 1. The mean age for the two groups did not differ. There was no significant difference in the mean serum retinol levels by gender.

The overall study population had a negative Z-score for height-for-age, indicating a shift towards a slowing in linear growth according to international criteria. Significantly more children were underweight (Z-score $<-2$ SD for weight-for-age) in the low serum retinol group. None of the children was wasted (Z-score $<2$ SD for weight-forheight).

\section{Household sociodemographic information}

Household demographic characteristics were similar between the two groups. The median (range) household size was $8(2-18)$ members, with a median of $4(1-10)$ adults; $38.1 \%$ of households had 10 or more members.

Of those households represented in the study, 61.9\% had access to a pit toilet, and $53.6 \%$ had access to tap water. Although electricity was available for $54.7 \%$ of the households, the main energy source for food preparation was wood, with more than $70 \%$ of the households using an open fire inside the dwelling. Although not significantly different $(P=0.068)$, it is worthwhile to note that $81.6 \%$ of children in the low serum retinol group were from households who made fires inside the dwelling, versus $64.4 \%$ in the normal serum retinol group.

The household's socioeconomic level is based on a composite measure of the living standards of the household. For this study, the standard-of-living index was derived by summing the following four components: access to tap water for drinking, access to a pit toilet, presence of electricity, and ownership of a radio. In each case the component was scored 1 if the household had the item, and 0 if it did not. The household standard-of-living index ranged from 0 to 4 . The average (SD) index for the total population was 2.5 (1.2), with no significant difference between the two groups, 2.6 (1.2) and 2.4 (1.2) in the low and normal serum retinol groups, respectively.

The care-givers were asked to consider a set of 11 problems which households normally experience. They were asked to rate the extent to which they felt that their household was affected by each of these problems. 'Severe' was given a score of 3, 'moderate' a score of 2 , 'minor' a score of 1 , and 'none' a score of 0 . The calculated average (SD) score of 0.15 (0.24) for the total group, with no significant difference between the two groups, showed that problems within the household were not perceived as major.

Table 1 Characteristics of the children according to serum retinol levels, using $20 \mu \mathrm{g} \mathrm{dl}^{-1}$ as the cut-off point

\begin{tabular}{|c|c|c|c|}
\hline & $\begin{array}{c}\text { All } \\
(n=97)\end{array}$ & $\begin{array}{c}<20 \mu \mathrm{g} \mathrm{dl}^{-1} \\
(n=38)\end{array}$ & $\begin{array}{c}\geqslant 20 \mu \mathrm{g} \mathrm{dl}^{-1} \\
(n=59)\end{array}$ \\
\hline \multicolumn{4}{|l|}{ Age in months } \\
\hline mean (SD) & $15.1(6.9)$ & $15.2(8.7)$ & $15.0(5.2)$ \\
\hline $95 \%$ confidence interval & $13.7 ; 16.5$ & $12.4 ; 18.0$ & $13.7 ; 16.3$ \\
\hline \multicolumn{4}{|l|}{ Serum retinol in $\mu \mathrm{g} \mathrm{dL}^{-1}$} \\
\hline mean (SD) & $22.1(6.5)$ & $15.7(3.0)$ & $26.2(4.6)^{\star \star \star}$ \\
\hline $95 \%$ confidence interval & $20.8 ; 23.4$ & $14.7 ; 16.6$ & $25.0 ; 27.4$ \\
\hline \multicolumn{4}{|l|}{ Gender } \\
\hline$\%$ boys $(95 \% \mathrm{Cl})$ & $51.5(41.6 ; 61.4)$ & $55.3(39.5 ; 71.1)$ & $49.1(36.4 ; 61.8)$ \\
\hline$\%$ girls $(95 \% \mathrm{Cl})^{\prime}$ & $48.5(38.6 ; 58.4)$ & $44.7(28.9 ; 60.5)$ & $50.9(38.2 ; 63.6)$ \\
\hline \multicolumn{4}{|l|}{ Position of child in family } \\
\hline$\%$ first born $(95 \% \mathrm{Cl})$ & $43.3(33.5 ; 53.1)$ & $34.2(19.1 ; 49.3)$ & $49.1(36.3 ; 61.9)$ \\
\hline$\%$ 2nd-4th child $(95 \% \mathrm{Cl})$ & $40.2(30.4 ; 50.0)$ & $42.1(26.4 ; 57.8)$ & $39.0(26.6 ; 51.4)$ \\
\hline$\% \geqslant 5$ th child $(95 \% \mathrm{Cl})$ & $16.5(9.1 ; 23.9)$ & $23.7(10.2 ; 37.2)$ & $11.9(3.6 ; 20.2)$ \\
\hline \multicolumn{4}{|l|}{ Anthropometric values } \\
\hline \multicolumn{4}{|l|}{ Height-for-age Z-score } \\
\hline Mean (SD) & $-0.97(0.97)$ & $-0.94(1.09)$ & $-0.98(0.89)$ \\
\hline $95 \% \mathrm{Cl}$ & $-1.16 ;-0.78$ & $-1.29 ;-0.59$ & $-1.21 ;-0.75$ \\
\hline$\%$ stunted $(95 \% \mathrm{Cl})$ & $10.4(4.3 ; 16.5)$ & $13.5(2.7 ; 24.3)$ & $8.5(1.4 ; 15.6)$ \\
\hline \multicolumn{4}{|l|}{ Weight-for-age Z-score } \\
\hline Mean (SD) & $-0.12(1.07)$ & $-0.26(1.18)$ & $-0.01(1.00)$ \\
\hline $95 \% \mathrm{Cl}$ & $-0.33 ; 0.09$ & $-0.63 ; 0.11$ & $-0.26 ; 0.24$ \\
\hline$\%$ underweight $(95 \% \mathrm{Cl})$ & $3.1(1.0 ; 8.5)$ & $8.1(1.6 ; 21.8)$ & $0.0(0 ; 6.5)^{\star}$ \\
\hline \multicolumn{4}{|l|}{ Weight-for-height Z-score } \\
\hline Mean (SD) & $0.74(1.01)$ & $0.54(1.00)$ & $0.86(1.00)$ \\
\hline $95 \% \mathrm{Cl}$ & $0.54 ; 0.94$ & $0.22 ; 0.86$ & $0.61 ; 1.11$ \\
\hline$\%$ wasted $(95 \% \mathrm{Cl})$ & $0.0(0 ; 3.8)$ & $0.0(0 ; 8.8)$ & $0.0(0 ; 6.5)$ \\
\hline$\%$ overweight $(95 \% \mathrm{Cl})$ & $7.3(3.2 ; 14.8)$ & $5.4(0.6 ; 18.2)$ & $8.5(1.4 ; 15.6)$ \\
\hline
\end{tabular}

Difference between the normal and low serum retinol group: ${ }^{*} P<0.05 ;{ }^{* \star *} P<0.001$. 
Table 2 Breastfeeding and weaning practices according to serum retinol levels

\begin{tabular}{|c|c|c|c|}
\hline & $\begin{array}{c}\text { All } \\
(n=97)\end{array}$ & $\begin{array}{c}<20 \mu \mathrm{g} \mathrm{dl}^{-1} \\
(n=38)\end{array}$ & $\begin{array}{c}\geqslant 20 \mu \mathrm{g} \mathrm{dl}^{-1} \\
(n=59)\end{array}$ \\
\hline Initiated breastfeeding (\%) & 97.9 & 100.0 & 96.5 \\
\hline Stopped breastfeeding during first year (\%) & 18.6 & 10.5 & 23.7 \\
\hline Introduction of solids before 4 months (\%) & 45.8 & 45.9 & 45.7 \\
\hline \multicolumn{4}{|l|}{$\begin{array}{l}\text { Frequency of usual intake of foods } \\
\text { rich in vitamin } A \text { and } \beta \text {-carotene (\%) }\end{array}$} \\
\hline \multicolumn{4}{|l|}{ Breast milk } \\
\hline Every day & 66.7 & 70.6 & 64.3 \\
\hline Never & 33.3 & 29.4 & 35.7 \\
\hline \multicolumn{4}{|l|}{ Formula milk } \\
\hline Every day & 21.1 & 14.7 & 25.0 \\
\hline Most days & 1.1 & 2.9 & 0.0 \\
\hline Never & 77.8 & 82.4 & 75.0 \\
\hline \multicolumn{4}{|l|}{ Egg } \\
\hline Most days & 3.3 & 8.8 & 0.0 \\
\hline Once a week & 6.7 & 8.8 & 5.4 \\
\hline Seldom & 72.2 & 58.8 & 80.4 \\
\hline Never & 17.8 & 23.5 & 14.3 \\
\hline \multicolumn{4}{|l|}{ Carrot } \\
\hline Once a week & 2.2 & 0.0 & 3.6 \\
\hline Seldom & 11.1 & 11.8 & 10.7 \\
\hline Never & 86.7 & 88.2 & 85.7 \\
\hline \multicolumn{4}{|l|}{ Pumpkin } \\
\hline Most days & 65.6 & 52.9 & 73.2 \\
\hline Once a week & 27.8 & 35.3 & 23.2 \\
\hline Seldom & 5.6 & 8.8 & 3.6 \\
\hline Never & 1.1 & 2.9 & 0.0 \\
\hline \multicolumn{4}{|l|}{ Imifino } \\
\hline Most days & 1.1 & 0.0 & 1.8 \\
\hline Once a week & 21.1 & 26.5 & 17.9 \\
\hline Seldom & 35.6 & 29.4 & 39.3 \\
\hline Never & 42.2 & 44.1 & 41.1 \\
\hline \multicolumn{4}{|l|}{ Spinach } \\
\hline Once a week & 2.2 & 2.9 & 1.8 \\
\hline Seldom & 42.2 & 32.3 & 48.2 \\
\hline Never & 55.6 & 64.7 & 50.0 \\
\hline $\begin{array}{l}\text { Child ate a food rich in vitamin A or } \\
\beta \text {-carotene the day prior to the interview }\end{array}$ & 536 & 421 & 610 \\
\hline
\end{tabular}

\section{Food used in the bousebold}

There was no significant difference between the two groups regarding the regular sources of food for the household. Food was mainly bought from the local shops, supplemented by some food grown in either their own home garden or a communal garden. Only $4.1 \%$ of households received food from a welfare or nongovernmental organization.

Food items usually bought by more than $50 \%$ of the care-givers were maize meal (97.9\%), beans (96.9\%), sugar (94.6\%), potatoes (91.8\%), rice (90.7\%), flour (85.6\%), oil (75.3\%), samp (71.1\%) and tea (58.8\%). Vegetables were bought by $29.9 \%$ of the care-givers. Significantly more care-givers in the low serum retinol group bought fruit and fresh milk as compared to the normal serum retinol group ( $13.2 \%$ vs. $0 \%$ for fruit; and $13.2 \%$ vs. $1.7 \%$ for fresh milk). There was no difference between the two groups in the livestock owned by the households. For the total study population, 34.0\% owned cattle, $22.7 \%$ slaughtered cattle and $12.4 \%$ milked the cows. Goats were owned by $44.3 \%$ and $30.9 \%$ slaughtered goats, while only $2.1 \%$ milked the goats. Chickens were owned by $68.0 \%$; 64.9\% slaughtered chickens and $49.5 \%$ used eggs laid by the chickens.
The prevalence of home gardens was 44.3\% (36.8\% and $49.2 \%$ for the low and normal serum retinol groups, respectively). There was no significant difference in the food grown in the home gardens between the two groups. The following $\beta$-carotene-rich fruits and vegetables were grown in the home gardens: pawpaw (12.4\%), pumpkin (34.0\%), imifino* (27.8\%) and carrot (8.2\%).

There was no significant difference in the percentage of households getting food from a communal garden $(13.5 \%$ and $20.7 \%$ for the low and normal serum retinol groups, respectively). The following $\beta$-carotene-rich fruits and vegetables were obtained from a communal garden: carrot (12.4\%), imifino (11.3\%), pumpkin (7.2\%) and pawpaw (1.0\%).

Household food security was determined using the hunger scale of the Community Childhood Hunger Identification Project (CCHIP) ${ }^{15}$. The scale consists of eight items, and food insecurity is indicated by five or more positive responses. Using this scale, $10.5 \%$ and $12.3 \%$ of households in the low and normal serum retinol groups, respectively, were classified as household food insecure.

\footnotetext{
* A dark green leafy vegetable.
} 


\section{Child feeding patterns}

Breast-feeding and complementary feeding practices are indicated in Table 2. Since two-thirds of the children were still being breast-fed at the time of the survey, the mean duration of breast-feeding was not calculated. However, in the low serum retinol group 10.5\% of infants were taken off the breast before their first birthday, versus $23.7 \%$ in the normal serum retinol group.

None of the children was introduced to solid foods during the first 2 months after birth. There was no significant difference between the two groups in the type of first food, with the majority (76.3\%) of the mothers giving maize meal porridge first.

The unquantified food frequency questionnaire showed no marked differences between the two groups regarding foods given routinely to the children. Staple foods consumed by most of the children were bread, maize meal porridge, rice and potatoes. Infant cereals were consumed by $11.1 \%$ of the children. Meat and chicken were consumed by approximately half of the children, once a week. Fish was seldom consumed. Fruits consumed were mostly oranges and bananas, which were both consumed once a week. Mango and pawpaw, both good sources of $\beta$-carotene, were not consumed by any of the children. The frequency of intake of foods rich in vitamin $\mathrm{A}$ and $\beta$-carotene is shown in Table 2. Liver was consumed by $8.9 \%$ of the children, although seldom.

Care-givers were asked whether the child consumed either liver, eggs, dark green leafy vegetables or a yellow fruit/vegetable the previous day. Although not statistically significant, there was a trend for more children in the normal serum retinol group to have eaten at least one of these food items the previous day, as compared to the children in the low vitamin A group (61.0\% vs. $42.1 \%)$.

\section{Child's bealth status and bealth care practices}

There was no difference in the sources of information on health care and nutrition between the two groups. For the total study population, care-givers obtained information on nutrition and health care from the Isizinda (87.6\%), clinic (81.4\%), radio (49.5\%), friends (4.1\%), newspapers (3.1\%) and family (3.1\%).

Health care practices are indicated in Table 3. Home deliveries (birth weights unavailable) were associated with a poor vitamin A status. Although not statistically significant $(P=0.0576)$, there was a tendency for children in the normal serum retinol group to attend the Isizinda more often. More children in the low serum retinol group were taken to the clinic because they were ill during the month prior to the study, indicating children in the normal serum retinol group had a better health status. All the children who had experienced a previous episode of measles were in the low serum retinol group.

Diarrhoea disease is directly related to the quality of water and sanitation services, as well as behaviours that are embodied in various sanitation and hygiene practices.
Table 3 Health care practices and health status of the child according to serum retinol levels

\begin{tabular}{|c|c|c|c|}
\hline & $\begin{array}{c}\text { All } \\
(n=97)\end{array}$ & $\begin{array}{c}<20 \mu \mathrm{g} \mathrm{dl}^{-1} \\
(n=38)\end{array}$ & $\begin{aligned} \geqslant & 20 \mu \mathrm{g} \mathrm{dl}^{-1} \\
& (n=59)\end{aligned}$ \\
\hline \multicolumn{4}{|l|}{ Place of birth } \\
\hline Hospital (\%) & 77.1 & 63.2 & $86.2^{\star \star}$ \\
\hline Home (\%) & 22.9 & 36.8 & 13.8 \\
\hline $\begin{array}{l}\text { Number of visits to Isizinda } \\
\text { during previous year (SD) }\end{array}$ & $7.3(2.8)$ & $6.6(2.6)$ & $7.8(2.8)$ \\
\hline \multicolumn{4}{|l|}{$\begin{array}{l}\text { During the last month, the } \\
\text { child was taken to: }\end{array}$} \\
\hline doctor (\%) & 23.8 & 26.7 & 22.2 \\
\hline clinic (\%) & 17.9 & 33.3 & $9.3^{\star *}$ \\
\hline mobile clinic (\%) & 9.5 & 13.3 & 7.4 \\
\hline traditional healer (\%) & 3.6 & 6.7 & 1.8 \\
\hline hospital (\%) & 4.8 & 3.3 & 5.6 \\
\hline $\begin{array}{l}\text { Previous episode of measles } \\
(\%)\end{array}$ & 4.3 & 11.0 & $0.0^{*}$ \\
\hline
\end{tabular}

Difference between the normal and low serum retinol group: ${ }^{*} P \leqslant 0.05$; ${ }^{\star \star} P \leqslant 0.01$.

Thus, occurrence of diarrhoea can be treated as an indicator of hygiene and sanitation conditions. There was no difference in the prevalence of diarrhoea between the two groups. Overall, 19.3\% of children had diarrhoea during the 2-week period prior to the survey. There were no significant differences between the two groups for dietary adjustments made or treatment given when the child experienced an episode of diarrhoea.

\section{Indicators of psychosocial care}

A wide range of maternal characteristics can potentially influence the nutritional status of the child. The average (SD) age of the care-givers was 28.8 (9.2) years (range: 14.2-53.4 years), with no significant difference between the two groups. For the sample of mothers $(n=71)$ only, they have given birth approximately three times by the age of about 27 years. Characteristics of the care-givers are given in Table 4. All the study children in the care of widowed care-givers were in the low serum retinol group.

There was no significant difference in the self-reported health status of the care-giver. Nearly 90\% (88.2\%) of the care-givers reported that they were seldom sick or never sick.

The care-giver's attitude towards family life, which was used as one of the indicators of psychosocial care, was found to be significantly different between the two groups. The women spent little time away from their own homes, for example on average, the care-givers reported visiting friends or relatives outside the village less than once in the past year.

The care-givers were asked how much support they got from family and non-family in times of difficulty. 'A lot' was given a score of 2 , 'a little' a score of 1 and 'nothing' a score of 0 . The average score for support was $0.4 \pm 0.2$ for both groups separately. In times of difficulty, support is usually given by other household members, and to a lesser extent by family members who are not part of the household. Little support was given by neighbours and 
Table 4 Characteristics of the care-givers according to the child's serum retinol levels

\begin{tabular}{lccc}
\hline & $\begin{array}{c}\text { All } \\
(n=97)\end{array}$ & $\begin{array}{c}<20 \mu \mathrm{gll}^{-1} \\
(n=38)\end{array}$ & $\begin{array}{c}\geqslant 20 \mu \mathrm{g} \mathrm{dl}^{-1} \\
(n=59)\end{array}$ \\
\hline Marital status & & & \\
$\quad$ Married (\%) & 34.0 & 26.3 & 39.0 \\
Unmarried (\%) & 59.8 & 57.9 & 61.0 \\
$\quad$ Widowed (\%) & 6.2 & 15.8 & $0.0^{\star \star}$ \\
years or less formal education (\%) & 34.3 & 40.5 & 30.6 \\
Positive attitude towards family life (\%) & 48.8 & 26.3 & $62.7^{\star \star \star}$ \\
Number of vitamin A-rich foods listed & & & 42.4 \\
None (\%) & 37.1 & 29.0 & 28.8 \\
One (\%) & 28.9 & 29.0 & 25.4 \\
Two (\%) & 27.8 & 31.6 & 3.4 \\
Three (\%) & 6.2 & 10.5 & \\
\hline
\end{tabular}

Difference between the normal and low serum retinol group: ${ }^{\star \star} P \leqslant 0.01 ;{ }^{\star \star \star} P \leqslant 0.001$.

friends, with hardly any support from community organizations, welfare organizations or the church.

The care-givers were asked to name three food items which are good sources of vitamin A; $15.5 \%$ of the caregivers did not attempt to name any food as they did not know. The rest listed a total of 27 food items, of which 10 were good sources of vitamin A. Foods rich in vitamin A listed by the care-givers were (with the percentage of caregivers naming the food item in brackets): imifino (37.1\%), pumpkin (26.8\%), carrot (13.4\%), egg (8.2\%), butternut (7.2\%), spinach $(5.1 \%)$, milk (3.1\%), sweet potato $(2.1 \%)$, liver (1.0\%) and mango (1.0\%). The percentage of caregivers who could name either one, two or three correct food items is shown in Table 4. Although there was no statistically significant difference between the two groups, there was a tendency for care-givers in the normal serum retinol group not to be able to name any foods rich in vitamin A. There were no cultural-specific food taboos and beliefs regarding feeding of the young child in this community.

\section{Multivariate analysis}

A multiple variable regression model was developed using the variables that were found to be statistically significant in the bivariate analysis. However, being underweight, having measles and being widowed were not included in the model because of small numbers. When controlling for each of the others, three variables were statistically significant, namely: the attitude of the care-giver towards family life $(P=0.0023)$, the place of birth $(P=0.0184)$ and whether the child was taken to a clinic for an illness during the previous month $(P=0.0231)$. There was no interaction between any of the variables included in the model; therefore, only the main effects are reported.

\section{Discussion}

The $39.2 \%$ prevalence of serum retinol levels $<20 \mu \mathrm{g} \mathrm{dl}^{-1}$ indicates that subclinical vitamin A deficiency is a problem of public health significance in this rural South African community. With one out of three preschool children having serum retinol levels $<20 \mu \mathrm{g} \mathrm{dl}^{-1}$, the rates are similar to the national level $(33 \%)^{1}$.

In this low socioeconomic rural community we identified three main factors associated with vitamin A status of children aged 6-24 months. The fact that a higher proportion of children taken to a clinic because of an illness during the month prior to the survey were in the low serum retinol group suggests an association between health status and vitamin A status. The fact that all children who had experienced a previous episode of measles and all underweight children were in the low serum retinol group supports this.

Although not statistically significant, there were a few practices which could influence the child's health status that tended $(P<0.1)$ to be associated with variation in serum retinol levels. The smoke of an open fire made for cooking purposes inside the dwelling pollutes the air which could affect the child's health, especially regarding upper respiratory tract infections. Children in the normal serum retinol group were brought to the Isizinda for regular growth monitoring more often than children in the low serum retinol group. Besides regular growth monitoring, health and nutrition education at the Isizinda focuses on, for example, breast-feeding, complementary feeding and diarrhoea - all of which can influence the vitamin A status of a child. In this community, regular attendance at the Isizinda is recommended and is indicative of the caring capacity of the care-giver.

The care-giver's expression of 'satisfaction with her family life', which was used as one of the indicators of psychosocial care, was found to be the key maternal indicator for child serum retinol levels. This is an important observation, since the care-giver's emotional well-being can influence the quality of care she can provide. In both Bangladesh ${ }^{16}$ and Mexico it has been shown that mothers that were rated as 'happy' had the best nourished children ${ }^{17}$. In addition, social networks, both as a source of information and support to the mother, are expected to be beneficial for her care-taking ability. Women in rural areas in South Africa spend little time away from their own homes. This is shown by the fact that, on average, the 
care-givers reported visiting friends or relatives outside the village less than once in the past year.

This study also showed that, in this rural community, children who were born at home were more likely to present with low serum retinol levels. This is an important observation, especially in the African context. In this community it is estimated that approximately $21 \%$ of children are born at home. The mothers of these children usually receive no antenatal or postnatal care at a health facility. Traditional midwives, local women with little formal education, are usually involved in the delivering of the babies. Although little data are available on the myths and rituals associated with home deliveries, we have previously shown that children in this community who were born at home were generally put on the breast for the first time the day after birth ${ }^{18}$. This practice deprives the infant of the full benefit of the protection against various enteric infections provided by the antibodies in the colostrum. Nutritional practices associated with home deliveries should be further investigated.

All the children in the care of widowed care-givers were in the low serum retinol group. Although not significant in the multivariate analysis model, this should not be overlooked, as evidence from Ghana indicated that the level of per capita consumption is substantially lower in households headed by divorced and widowed women than in those headed by married women ${ }^{19}$.

Although we could not show an association between dietary practices and vitamin A status, this aspect should not be ignored since a strong association between serum vitamin $\mathrm{A}$ levels and the frequent consumption of foods rich in $\beta$-carotene and vitamin $\mathrm{A}$ has been reported ${ }^{20}$. The appropriate lack of association between dietary practices and vitamin A levels found in our study could be because of small sample size, or monotonous dietary practices. A study on primary school children in the same area showed that these children consumed a diet very low in vitamin $\mathrm{A}$ content ${ }^{21}$. Increased intake of food items rich in $\beta$-carotene and vitamin A should be promoted by all means possible. In order to increase the availability of $\beta$-carotene-rich foods, the Medical Research Council is in the process of developing a targeted community-based food production programme.

Although care-givers of children in the low serum retinol group bought significantly more fruit, it is unlikely that this could affect the serum retinol levels, since the fruit consumed by the children were mainly oranges and bananas, both poor sources of vitamin A. The higher percentage of care-givers in the low serum retinol group buying fresh milk would also not affect the serum retinol levels of the children, as we have previously indicated that fresh milk is seldom consumed by children in this age category in this community ${ }^{18}$. Low income not only restricts the ability to buy foods rich in protective nutrients but also limits the access to food retailers where healthy food can be purchased more cheaply. The people rely on public transport to move in and out of the area. They rely on the local shop for many of their food purchases. Food in the local shop is often more expensive than in the big supermarkets in the cities, and the variety of available food items is limited.

In summary, this study showed that children who are in the care of widows, who are underweight, who previously had measles, who are taken to the clinic because of an illness, or who are born at home, are at risk for low vitamin A status. Interventions should address, amongst others, home/hospital deliveries, and therefore ante- and postnatal care; regular growth monitoring; and food preparation methods (open fire inside the dwelling).

Although long-term prevention of vitamin A deficiency should rely on efforts to improve the local diet, micronutrient malnutrition should not be viewed as an isolated health problem. Approaches aimed at improving vitamin A status should include interventions directed to environmental and health-associated behavioural factors. Although some factors associated with low vitamin A status (e.g. widowed care-giver) cannot be changed, they can be used as markers for children likely to be at risk.

\section{Acknowledgements}

We would like to express our sincere appreciation to the South African Sugar Association for their financial support. We thank Ms MP Marais, Mr DeW Marais and Mr EAR Harmse for technical support; Dr MA Dhansay for drawing the blood; Ms JA Laubscher for her assistance with the statistical analysis; Dr PL Jooste for critically reviewing this manuscript; Mr M Phungula and our team of nutrition monitors for their invaluable support and dedication to the study; and the care-givers and their children who participated in this study.

\section{References}

1 South African Vitamin A Consultative Group (SAVACG). Anthropometric, vitamin A, iron and immunisation coverage status in children aged 6-71 months in South Africa, 1994. S. Afr. Med.J. 1996; 86: 354-7.

2 West KP Jr, Sommer A. Delivery of Oral Doses of Vitamin A to Prevent Vitamin A Deficiency and Nutritional Deficiency: a State-of-the-Art Review. United Nations ACC/SCN Nutrition Policy Discussion Paper No. 2. Rome: Food and Agricultural Organization, 1987.

3 Van Stuijvenberg ME, Kvalsvig JD, Faber M, Kruger M, Kenoyer DG, Benadé AJS. Effect of iron-, iodine-, and $\beta$ carotene-fortified biscuits on the micronutrient status of primary school children: a randomized controlled trial. $\mathrm{Am}$. J. Clin. Nutr. 1999; 69: 497-503.

4 UNICEF. Strategy for Improved Nutrition of Children and Women in Developing Countries. UNICEF: New York, 1990.

5 Nestel P, Herrera MG, El Amin A, Fawzi W, Mohammed KA, Weld L. Risk factors associated with xerophthalmia in northern Sudan. J. Nutr. 1993; 123: 2115-21.

6 Hussain A, Kvale G. Environmental conditions, health behavior, and mortality in siblings as risk indicators of night blindness. Am. J. Trop. Med. Hyg. 1996; 54: 309-12. 
7 Ahmed F, Khan MR, Faruque O, Taj S, Hyderi T, Jackson AA. Serum retinol is influenced by social factors and antioxidant nutrients among adolescent girls in urban Bangladesh. Int.J. Food Sci. Nutr. 1998; 49: 39-44.

8 Rosen DS, Sloan NL, del Rosario A, de la Paz TC. Risk factors for vitamin A deficiency in rural areas of the Philippines. J. Trop. Pediatr. 1994; 40: 82-7.

9 Faber M, Benadé AJS. Nutritional status and dietary practices of 4-24-month-old children from a rural South African community. Public Health Nutr. 1999; 2: 179-85.

10 Faber M, Oelofse A, Benadé AJS. A model for a communitybased growth monitoring system. Afr. J. Health Sci. 1998; 5: $72-8$.

11 Catignani GL, Bieri JG. Simultaneous determination of retinol and $\alpha$-tocopherol in serum or plasma by liquid chromatography. Clin. Chem. 1983; 29: 708-12.

12 Jelliffe DB, Jelliffe EFP. Anthropometry: major measurements. In: Jelliffe DB, Jelliffe EFP, eds. Community Nutritional Assessment, 1st edn. Oxford: Oxford University Press, 1989; 68-104.

13 Gross R, Kielman A, Korte R, Schoeneberger H, Schultink W. Guidelines for Nutrition Baseline Surveys in Communities, Version 1.2. Thailand: TW System (Thailand) Co., Ltd, 1997.

14 Hamill PVV, Drizd TA, Johnson CL, Reed RB, Roche AF, Moore WM. Physical growth: National Center for Health Statistics percentiles. Am. J. Clin. Nutr. 1979; 32: 607-29.
15 Campbell CC. Food insecurity: a national outcome or a predictor variable? J. Nutr. 1991; 121: 408-15.

16 Range SKK, Naved R, Bhattarai S. Child Care Practices Associated with Positive and Negative Nutritional Outcomes for Children in Bangladesh: a Descriptive Analysis. FCND Discussion Paper No. 24. Washington, DC: Food Composition and Nutrition Division, 1997.

17 Zeitlin MF. Child Care and Nutrition: the Findings from Positive Deviance Research. Medford, MA: Tufts University, School of Nutrition, 1994.

18 Faber M, Oelofse A, Kriek AJ, Benadé AJS. Breastfeeding and complementary feeding practices in a low socio-economic urban and a low socio-economic rural area. S. Afr. J. Food Sci. Nutr. 1997; 9: 43-51.

19 Lloyd CB, Gage-Brandon AJ. Women's role in maintaining household: family welfare and sexual inequality in Ghana. Popul. Stud. 1993; 47: 115-31.

20 Hussain A, Kvåle G. Serum vitamin A in relation to socioeconomic, demographic and dietary characteristics in Bangladeshi children. Acta Paediatr. 1996; 85: 971-6.

21 Faber M, Smuts CM, Benadé AJS. Dietary intake of primary school children in relation to food production in a rural area in KwaZulu-Natal. Int. J. Food Sci. Nutr. 1999; 50: 57-64. 